\title{
Survey on the awareness of using painkillers among the University students of Bangladesh
}

\author{
*Mahmuda Naheed ${ }^{1}$, Naimul Alam Patwary1, M. Azad Uddin², Saiful Alam ${ }^{3}$ \\ ${ }^{1}$ Faculty of Health Science, Department of Pharmacy, Northern University Bangladesh, Dhaka, Bangladesh \\ ${ }^{2}$ Assistant Director, Credit Information Bureau, Bangladesh Bank, Dhaka, Bangladesh \\ ${ }^{3}$ Deputy Manager, Product Management Department, General Pharmaceutical Ltd. Dhaka, Bangladesh
}

\begin{abstract}
The aim of the study was to determine the Awareness of using Painkillers among the University Students of Bangladesh. The main objective of this survey was to determine the percentage of young adults using painkillers without prescription. The survey carried out among 300 students of different public and private universities. Data were collected using structured questionnaires containing 5 questions related to the students' demographics and 15 questions related to the awareness of using painkillers. Descriptive statistics, factor analysis and Chi square test were used for data analysis. A total of 300 questionnaires were completed and collected. Both male and female students studying in different public and private universities completed questionnaires distributed. The most important finding was $69 \%$ students are unaware about taking painkillers. The study concluded that the university students are not conscious about using painkiller. A big percentage of students use painkiller without physician's prescription.
\end{abstract}

Key Words: Awareness, painkillers, University students, Bangladesh.

\section{INTRODUCTION}

Pain is a common and growing problem in our societies. It is frequently associated with intentional and unintentional injuries, as well as illnesses and diseases that occur over a normal lifespan. Pain is a subjective symptom that cannot be objectively measured in the way that blood pressure or heart rate can be measured. The Oxford English Dictionary (OED) defines pain as; A primary condition of sensation or consciousness, the opposite of pleasure, the sensation which one feels when hurt (in body or mind); suffering, distress. Or: In specifically physical sense: Bodily suffering; a distressing sensation as of soreness (usually in a particular part of body). Pain is defined by the International Association for the Study of Pain (IASP) as 'an unpleasant sensory and emotional experience associated with actual or potential tissue damage, or described in terms of

\footnotetext{
*Corresponding Author:

Mahmuda Naheed, Senior Lecturer

Faculty of Health Science, Department of Pharmacy

Northern University Bangladesh

Dhaka, Bangladesh

E-mail: naheed2015@gmail.com

Contact No.: +8801671 079884
}

such damage' (Merskey \& Bogduk, 1994). However, the inability to communicate verbally does not negate the possibility that an individual is experiencing pain and is in need of suitable painrelieving treatment (Macintyre et al., 2010).

Pain is an unpleasant sensation localized to a part of the body. It is often described in terms of a penetrating or tissue-destructive process (e.g., stabbing, burning, twisting, tearing, squeezing) and/or of a bodily or emotional reaction (e.g., terrifying, nauseating, sickening). Furthermore, any pain of moderate or higher intensity is accompanied by anxiety and the urge to escape or terminate the feeling. These properties illustrate the duality of pain: it is both sensation and emotion. When acute, pain is characteristically associated with behavioral arousal and a stress response consisting of increased blood pressure, heart rate, pupil diameter, and plasma cortisol levels. In addition, local muscle contraction (e.g., limb flexion, abdominal wall rigidity) is often present (Harrison et al., 2005). Basically there are three types of pain: acute pain, chronic pain associated with malignant disease, and 
Table 1: Demographic characteristics of respondents.

\begin{tabular}{lll}
\hline Sex & n & \% \\
\hline Male & 138 & 46 \\
Female & 162 & 54 \\
\hline Age & & \\
\hline $18-21$ & 122 & 40.7 \\
$22-25$ & 156 & 52 \\
$26+$ & 22 & 7.3 \\
\hline Year of Education & & \\
\hline 1st year & 72 & 24 \\
2nd year & 77 & 25.7 \\
3rd year & 60 & 20 \\
4th year & 70 & 23.3 \\
Masters & 21 & 7 \\
\hline Living places & & \\
\hline Parents & 97 & 32.3 \\
Brother/sister & 20 & 6.7 \\
Uncle/Relative & 17 & 5.7 \\
Hostel & 156 & 52 \\
Others & 10 & 3.3 \\
\hline Money received from family other & & \\
than tuition fees & & \\
\hline yes & 221 & 73.7 \\
No & 79 & 26.3 \\
\hline Amount of Money received from & & \\
family other than tuition fees & & \\
\hline$<3000$ & 35 & 31.7 \\
3001 - 5000 & 29.7 \\
5001- 8000 & 11.7 \\
8000+ & & \\
\hline & & \\
\hline
\end{tabular}

chronic pain not associated with malignant disease. Acute pain is of short duration and lasts less than 3 to 6 months. Intensity of acute pain is from mild to severe. Causes of acute pain include postoperative pain, procedural pain, and traumatic pain. Acute pain usually subsides when the injury heals. Chronic pain lasts longer than 6 months and ranges in intensity from mild to severe. Chronic pain associated with malignancy includes the pain of cancer, acquired chronic pain and inflammation associated with disorders such as rheumatoid arthritis or osteoarthritis. (Roach et al., 2009) At present the principal treatment of pain non-steroidal anti inflammatory drugs (NSAIDs) (Buschmann et al., 2004). Examples of NSAIDs include paracetamol, celecoxib, rofecoxib etc.

In Bangladesh, self-medication is widespread (Chowdhury et al., 2009). This study is aiming to find out the Awareness of using Painkillers among the young adults of Dhaka city in Bangladesh. This survey was conducted on both public and private University students of Bangladesh. The awareness was mainly measured by the tendency of using painkillers by the young adults without prescription. Self-medication rate among higher educated population in Bangladesh were evaluated earlier but awareness regarding using painkillers has never been evaluated (Islam et al., 2007). In this survey we have evaluated the awareness of using Painkillers among the University Students of Bangladesh which has been characterized by four factors which are seeking help from physician while feeling pain, fulfilling prescription after consultation with a physician, taking the same drug without physicians' prescription for the same problem and how often using medicine without physicians prescription

The rate of self medication is very high in Bangladesh. The knowledge of OTC medicines and attitudes toward self-medication among higher educated population is not satisfactory (Islam et al., 2007). To date there seems to be shortage of studies investigating awareness of using painkillers among the educated young adults in Bangladesh.

\section{MATERIALS AND METHODS}

The study was a questionnaire based survey carried out from April 2010 to June 2010.The samples were selected randomly among students studying in different universities of Dhaka city. The universities were selected by using simple random sampling from the university list. A questionnaire was developed based on the parameters related to the awareness of using drugs such as consulting physician for the treatment of pain or before using medicine, fulfilling prescription, restricting self medication etc.

In this survey we have evaluated the awareness of using Painkillers among the University Students of Bangladesh which has been characterized by four factors which are, seeking help from physician while feeling pain, fulfilling prescription, taking the same drug without physicians' prescription for the same problem and how often using medicine without physicians' prescription. The questionnaires were distributed to the selected universities. The questionnaires were then randomly distributed to the students. Questionnaires were fulfilled by both male and female students studying in different public and private universities. 
The data were analyzed using Statistical program (SPSS $\left.{ }^{\circledR}\right)$ version 16 . The descriptive data, including demographic characteristics, distribution of respondents according to the awareness of drug use, were expressed in percentage. The factors related to the awareness were identified using Chi square test and significant variables were included in the logistic regression model.

\section{RESULTS AND DISCUSSION}

\section{Demographic of the participants}

The total number of questionnaires distributed was 500 and 300 completed forms were collected. This resulted in a response rate of $60 \%$. There were $46 \%$ male and $54 \%$ female. Demographic data including age, sex, level of education, living place and financial condition of the respondents are shown in Table 1. We found $46 \%$ male and $54 \%$ female respondents and most of them are between the ages of 22-25 (52\%). Mean age of respondents are 22.04. Most of the respondents (52\%) live in the hostel and $32.3 \%$ live with parents. Maximum students are financially solvent and get money from the family $(79 \%)$ and $41.4 \%$ students receive handsome amount of money (other than tuition fees) between the range of 30008000 taka per month. Mean amount of money received from the family is 3848.87 taka per month.

\section{Nature of pain among participants}

Overall we found that $89 \%$ of the participants felt pain. This data was stratified according to age, sex, year of education, money received from family other than tuition fees and living category (Table 3). Pain is experienced differently in male and female (Skvarc et al., 2004). In a study it has been found that chronic pain was significantly associated with older age, female gender, lower levels of completed education (Blyth et al., 2001). In our study we also found that women are more likely to feel pain $(52.4 \%)$ rather than male. Headache is one of the most common outpatient pain conditions encountered in both physician offices and emergency departments (Gallagher et al., 2005). In our study we observed several kinds of pain felt by the respondents (Table 2), among which headache is most common (53.3\%). Maximum students (50.3\%) do not consult with physician. Those who consulted, mainly consult with medicine specialists $(27.3 \%)$. Most of them used drug (35.7\%) and filled up
Table 2: Nature of pain among participants.

\begin{tabular}{lll}
\hline Feeling any kind of pain & $\mathbf{n}$ & $\mathbf{\%}$ \\
\hline Yes & 267 & 89.0 \\
No & 33 & 11.0 \\
\hline Type of pain & & \\
\hline Headache & 160 & 53.3 \\
Toothache & 28 & 9.3 \\
Abdominal pain & 39 & 13.0 \\
Neck pain & 14 & 4.7 \\
Others & 26 & 8.7 \\
\hline Consulted with physician & & \\
\hline Yes & 116 & 38.7 \\
No & 151 & 50.3 \\
\hline Kind of physician & & \\
\hline GP & 17 & 5.7 \\
Medicine & 82 & 27.3 \\
Others & 17 & 5.7 \\
\hline Drug used & & \\
\hline Yes & 107 & 35.7 \\
No & 9 & 3.0 \\
\hline Filled up prescription & & \\
\hline Yes & 88 & 29.3 \\
No & 28 & 9.3 \\
\hline
\end{tabular}

prescription (29.3\%). Respondents feel more pain $(39.7 \%)$ who are between the ages of 20 to 22 . Second year students feel more pain $(25.1 \%)$ than other year of students. Students received money from family other than tuition fees feels more pain $(74.2 \%)$. Students feel more pain who are living in hostel $(54.7 \%)$ or living alone (58.4) without family members ( $p$ value $<0.015$ and 0.003 respectively).

\section{Awareness of participants}

In this survey we have evaluated the awareness of using Painkillers among the University Students of Bangladesh which has been characterized by four factors, which are seeking help from physician while feeling pain, fulfilling prescription after consultation with a physician, taking the same drug without physicians' prescription for the same problem and how often using medicine without physicians' prescription. We considered those as an aware participant who seek help from physician while feeling pain, fulfilling prescription after consultation with a physician, not taking the same drug without physicians' prescription for the same problem and do not use medicine without physicians' prescription. In this survey we found that among 300 participants only 93 students were aware about taking painkillers. That is a large number of students $(69 \%)$ are unaware about taking painkillers. Awareness is closely related to self medication. 
Table 3: Nature of pain among participants according to demographic characteristics.

\begin{tabular}{|c|c|c|c|}
\hline \multirow{2}{*}{ Variables } & \multicolumn{2}{|c|}{ Feeling any kind of pain } & \multirow{2}{*}{$\begin{array}{c}\text { p-value (Chi- } \\
\text { square, d.f) }\end{array}$} \\
\hline & Yes & $\%$ & \\
\hline \multicolumn{4}{|l|}{ Sex } \\
\hline Male & 127 & $47.6 \%$ & \multirow[t]{2}{*}{$0.141(2.395,1)$} \\
\hline Female & 140 & $52.4 \%$ & \\
\hline \multicolumn{4}{|l|}{ Age Category } \\
\hline $18-20$ & 70 & $26.2 \%$ & \multirow{3}{*}{$0.286(2.502,2)$} \\
\hline $20-22$ & 106 & $39.7 \%$ & \\
\hline $22+$ & 91 & $34.1 \%$ & \\
\hline \multicolumn{4}{|c|}{ Year of Education } \\
\hline 1st year & 61 & $22.8 \%$ & \multirow{5}{*}{$0.46(3.616,4)$} \\
\hline 2nd year & 67 & $25.1 \%$ & \\
\hline 3rd year & 54 & $20.2 \%$ & \\
\hline 4 th year & 65 & $24.3 \%$ & \\
\hline Masters & 20 & $7.5 \%$ & \\
\hline \multicolumn{4}{|c|}{ Money received from family other than tuition fees } \\
\hline yes & 198 & $74.2 \%$ & \multirow[t]{2}{*}{$0.675(0.301,1)$} \\
\hline No & 69 & $25.8 \%$ & \\
\hline \multicolumn{4}{|c|}{ Whom do you live with? } \\
\hline Parents & 79 & $29.6 \%$ & \multirow{5}{*}{$0.015(12.360,4)$} \\
\hline Brother/sister & 16 & $6.0 \%$ & \\
\hline Uncle/Relative & 16 & $6.0 \%$ & \\
\hline Hostel & 146 & $54.7 \%$ & \\
\hline Others & 10 & $3.7 \%$ & \\
\hline \multicolumn{4}{|l|}{ Living category } \\
\hline \multicolumn{3}{|l|}{ Living with family } & \multirow[t]{2}{*}{$0.003(9.399,1)$} \\
\hline living alone & 156 & $58.4 \%$ & \\
\hline Total & 267 & & \\
\hline
\end{tabular}

Self-medication can be defined as obtaining and consuming drugs without the advice of a physician either for diagnosis, prescription or surveillance of treatment (Montastruc et al., 1997). Self-medication is practiced significantly worldwide. A study based on self medication conducted in Palestine, it was found that there is no statistical difference between respondents who reported practicing selfmedication based on gender (Sawalha et al., 2010). Whereas in our study, we found that male students are more aware (52\%) than female $(47.3 \%)$. A significantly higher proportion of young ( $<40$ years) male respondents had used self-medication than other groups (Shankar et al., 2002). In our study students between the ages of 20-22 shows more awareness than others. Second year and fourth year students are more aware than other year of students. Usually students living alone or living in hostel are more aware regarding using painkillers than those living with families (Table 4).
Table 4: Awareness of the students according to demographic characteristics.

\begin{tabular}{|c|c|c|c|}
\hline \multirow{2}{*}{ Variables } & \multicolumn{2}{|c|}{ Awareness of the students } & \multirow{2}{*}{$\begin{array}{l}\text { p-value (Chi- } \\
\text { square, d.f) }\end{array}$} \\
\hline & Aware & $\%$ & \\
\hline \multicolumn{4}{|l|}{ Sex } \\
\hline Male & 49 & $52.7 \%$ & $0.134(2.427,1)$ \\
\hline Female & 44 & $47.3 \%$ & \\
\hline \multicolumn{4}{|l|}{ Age Category } \\
\hline $18-20$ & 23 & $24.7 \%$ & \\
\hline $20-22$ & 44 & $47.3 \%$ & $0.308(2.365,2)$ \\
\hline $22+$ & 26 & $28.0 \%$ & \\
\hline \multicolumn{4}{|c|}{ Year of Education } \\
\hline 1st year & 18 & $19.4 \%$ & \\
\hline 2nd year & 26 & $28.0 \%$ & \\
\hline 3rd year & 19 & $20.4 \%$ & $0.388(4.137,4)$ \\
\hline 4 th year & 26 & $28.0 \%$ & \\
\hline Masters & 4 & $4.3 \%$ & \\
\hline \multicolumn{4}{|c|}{ Money received from family other than tuition fees } \\
\hline yes & 66 & $71.0 \%$ & $0.482(0.506,1)$ \\
\hline No & 27 & $29.0 \%$ & \\
\hline \multicolumn{4}{|c|}{ Whom do you live? } \\
\hline Parents & 18 & $19.4 \%$ & \\
\hline Brother/sister & 7 & $7.5 \%$ & $0.007(14.169,4)$ \\
\hline Uncle/Relative & 3 & $3.2 \%$ & \\
\hline Hostel & 62 & $66.7 \%$ & \\
\hline Others & 3 & $3.2 \%$ & \\
\hline \multicolumn{4}{|c|}{ Living category } \\
\hline \multicolumn{4}{|c|}{ Living with family } \\
\hline living alone & 65 & $69.9 \%$ & \\
\hline Total & 93 & & \\
\hline
\end{tabular}

\section{CONCLUSION}

Our study concluded that the university students are not conscious about using painkiller. Male students and students living alone are more aware. A big percentage of students $(69 \%)$ use painkiller without physician's prescription. Further studies regarding awareness needs to be conducted in Bangladesh.

\section{REFERENCES}

Blyth, F.M., March, L.M., Brnabic, A.J., Jorm, L.R., Williamson, M., Cousins, M.J. (2001). Chronic pain in Australia: a prevalence study, Pain, Volume 89, Issue2-3, Pages 127-34. [DOI]

Buschmann, H., Christoph, T., Friderichs, E., Maul, C. and Sundemann, B. (2004). Analgesics: From Chemistry and Pharmacology to Clinical Application, Journal of the National Medical Association, Volume 96, No. 4, Pp. 567. PMC:2594988

Chowdhury, M., Matin, F. and Chowdhury, S.F.A. (2009). Medication taking behavior of students attending a private 
university in Bangladesh, Int J Adolesc Med Health, Volume 21, Issue 3, Pages 361-370. [DOI] PMid:20014639

Gallagher, R.M. (2005). Headache Pain, The journal of American osteopathic association, Volume 105, Issue 4, Pages S7-S11. PMid:16249365

Harrison, T.R. (2005). Harrison's Principles of Internal Medicine, $16^{\text {th }}$ ed., Pp. 71-72.

Islam, S.M. (2007) Self-Medications among Higher Educated Population in Bangladesh: An Email-Based Exploratory Study, The Internet Journal of Health, Volume 5, Issue 2.

Macintyre, P.E., Scoot, A.D., Schug,A.S., Visser,J.E. and Walker,M.S. (2010). Acute pain management: Scientific evidence, $3^{\text {rd }}$ ed., Pp. 1.

Merskey, H.M., Bogduk N. (1994) Classification of Chronic Pain, $2^{\text {nd }}$ ed., IASP Press, Seattle, Pp. 211.
Montastruc, J.L., Bagheri, H., Geraud, T., Lapeyre Mestre M (1997) Pharmacovigilance of self-medication. Therapie 1997, Volume 52, Issue 2, Pages 105-110. PMid:9231503

Roach, S.S. \& Ford S.M. (2009). Roach's Introductory Clinical Pharmacology, $7^{\text {th }}$ Ed., Pp. 150-151.

Sawalha, A. (2010) Assessment of Self-Medication Practice among University Students in Palestine: Therapeutic and Toxicity Implications. The Islamic University Journal, Vol.15, No. 2, Pp. 67-82.

Shankar, P.R., Partha, P. and Shenoy, N. (2002) Selfmedication and non-doctor prescription practices in Pokhara valley, Western Nepal: a questionnaire-based study, BMC family practice, Volume 3, Issue 17. [DOI]

Skvarc, N.K. (2004) Prevalence of pain in family practice: gender issues, Journal of pain management, Volume 3, Issue 2, Pages 149-157. 